\title{
Promosi Kesehatan dan Kebijakan Physical Distancing Terhadap Perilaku Pencegahan COVID-
} 19

\author{
Achmad Lukman Hakim ${ }^{1} *$ \\ ${ }^{1}$ Laboratorium Fisiologi, Fakultas Kedokteran, Universitas Surabaya, Surabaya-Indonesia \\ * corresponding author: achmadlukmanhakim@gmail.com
}

\begin{abstract}
Coronavirus Disease 2019 (COVID-19) is a contagious disease caused by a coronavirus where the virus attacks the respiratory tract and can infect humans and animals. Therefore, preventive measures against breaking the chain of transmission of this infectious disease must be carried out as quickly as possible in breaking the chain of transmission of COVID-19. The research objective was to determine the relationship between health promotion through social media and physical distancing policies on behavioral prevention of COVID-19 in urban communities. The research method is quantitative with cross sectional research design. The population in this research is all urban people who live in the DKI Jakarta area. The sampling technique used accidental sampling of 100 respondents. The data used are primary data through distributing questionnaires and secondary data derived from Jakarta's COVID-19 monitoring data. Data analysis was performed univariate and bivariate with the Pearson product moment correlation test. The results showed the relationship between health promotion through social media (with $p$-value $=0.001$ and $r=$ 0.315 ) and physical distancing policies (with $p$-value $=0,000$ and $r=0.973$ ) on COVID-19 prevention behavior in urban communities. It is hoped that the government will not hesitate in carrying out policies in reducing the spread of COVID-19 and promoting coordination with various related parties.
\end{abstract}

Keywords: health promotion, physical distancing policies, social media

\begin{abstract}
Abstrak-Coronavirus Disease 2019 (COVID-19) adalah salah satu penyakit menular yang disebabkan oleh coronavirus dimana virus tersebut menyerang saluran pernafasan dan dapat menginfeksi manusia dan hewan. Oleh sebab itu, tindakan pencegahan terhadap memutus rantai penularan penyakit menular tersebut wajib dilakukan secepat mungkin dalam memutus mata rantai penularan COVID-19. Tujuan penelitian untuk mengetahui hubungan antara promosi kesehatan melalui media social dan kebijakan physical distancing terhadap perilaku pencegahan perilaku COVID-19 pada masyarakat perkotaan. Metode penelitian adalah kuantitatif dengan desain penelitian cross sectional. Populasi dalam penelitian adalah seluruh masyarakat perkotaan yang berdomisili di wilayah DKI Jakarta. Teknik pengambilan sampel menggunakan accidental sampling sebanyak 100 responden. Data yang digunakan data primer melalui penyebaran kuesioner dan data sekunder yang berasal dari data pemantauan COVID-19 DKI Jakarta. Analisis data dilakukan secara univariat dan bivariat dengan uji korelasi pearson product moment. Hasil penelitian menujukkan hubungan promosi kesehatan melalui media sosial (dengan $p$-value $=0,001$ dan $r=0,315$ ) dan kebijakan physical distancing (dengan $p$-value $=0,000$ dan $r=0,973$ ) terhadap perilaku pencegahan COVID-19 pada masyarakat perkotaan. Diharapkan pemerintah tidak ragu dalam menjalankan kebijakan dalam menekan penyebaran COVID-19 serta mengedepankan koordinasi dengan berbagai pihak terkait.
\end{abstract}

Kata kunci: kebijakan physical distancing, media sosial, promosi kesehatan

\section{PENDAHULUAN}

Pada Desember 2019, kasus penyakit pneumonia pertama kali dilaporkan di wilayah Wuhan, Provinsi Hubei (Rothan dan Byrareddy, 2020). Pneumonia adalah kondisi dimana alveoli pada salah satu atau kedua paru-paru terisi oleh cairan yang mengakibatkan terganggunya pertukaran oksigen disebabkan oleh bakteri, virus maupun jamur (Mia dan Mursid, 2020). Menurut World Health Organization terhitung mulai tanggal 24 Maret 2020 sebanyak terdapat 634.835 kasus dan 33.106 jumlah kematian di seluruh dunia (WHO, 2020). Pada tanggal 11 Februari 2020, World Health Organization menamakan virus baru dengan nama Severa acute respiratory syndrome coronavirus-2 (SARS-CoV-2) dan dinamakan penyakitnya sebagai Coronavirus disease 2019 (COVID-19) (Perhimpunan Dokter Paru Indonesia, 2020). Pandemi global terjadi di Indonesia berdasarkan laporan terakhir pada tanggal 14 Mei 2020 kasus COVID-19 di Indonesia berkisar 16.006 jiwa. Wilayah DKI Jakarta sebagai provinsi yang paling tinggi terpapar virus COVID-19, berdasarkan data pemantauan COVID-19 DKI Jakarta pada tanggal 14 Mei 2020 yaitu berkisar 5.617 jiwa (Dinkes DKI Jakarta, 
2020). COVID-19 merupakan penyakit menular yang memilki potensi menimbulkan kedaruratan kesehatan masyarakat dalam kondisi saat ini (Dalinama, 2020).

Peran pemerintah sangat penting dalam memutus rantai penyebaran COVID-19, pada pemerintah wilayah DKI Jakarta mengeluarkan berbagai kebijakan dalam upaya memutus rantai penyebaran COVID-19 yaitu dimulai dari penerapan physical distancing, pelaksanaan Pembelajaran Jarak Jauh (PJJ), Work From Home (WFH), pembatasan trasnportasi, kegiatan yang mengundang massa serta kebijakan Pembatasan Sosial Berskala Besar (PSBB) (Mitasari, 2020). Walaupun demikian, pemerintah pusat juga mengambil peran dalam upaya menangani COVID-19 seperti melakukan upaya promosi kesehatan mengajak masyarakat untuk selalu melakukan cuci tangan pakai sabun, memakai masker apabila keluar rumah, memberikan informasi-informasi kesehatan dalam upaya pencegahan virus, dan membuat kebijakan physical distancing guna memutus mata rantai penyebaran pada masyarakat. Namun kebijakan tersebut belum berhasil maksimal, karena masih banyaknya masyarakat yang tidak patuh dalam menaati kebijakan yang dibuat (Dana, 2020)

Menurut teori pencegahan perilaku, terdapat faktor-faktor yang mempengaruhi perilaku pencegahan COVID-19 yaitu kepercayaan, umur, pendidikan, status ekonomi, dan promosi kesehatan melalui media social (Budhiarto, 2020), dan berdasarkan teori Lawrence Green kesehatan individu dipengaruhi oleh dua faktor pokok yaitu faktor perilaku (behavior causes) dan faktor diluar perilaku (non-behavior causes). Sementara faktor perilaku (behavior causes) dipengaruhi oleh tiga faktor yakni : faktor predisposisi (Predisposing Factors) yaitu usia, pekerjaan, pendidikan, pengetahuan dan sikap, faktor pemungkin (Enabling Factors) yaitu lingkungan fisik dan jarak ke fasilitas kesehatan, dan faktor penguat (Reinforcing Factors) yaitu kebijakan pemerintah, dukungan keluarga, dan tokoh masyarakat (Notoatmodjo, 2014).

Hasil penelitian yang dilakukan oleh Putri, Rezal, dan Akifah, menunjukkan hasil diketahui bahwa ada perbedaan perilaku pencegahan penyakit gastritis pada kelompok audio visual dan leaflet dengan $p=0,04$ atau $p$-value $<0,05$. Hal ini menunjukkan bahwa penyuluhan media audio visual efektif terhadap tindakan responden tentang perilaku pencegahan penyakit gastritis (Putri, Rezal, dan Akifah, 2017). Promosi kesehatan merupakan metode memandirikan masyarakat guna mempertinggi kesehatannya melalui berbagai macam kegiatan informasi dan edukasi (Notoatmodjo, 2014). Hasil penelitian yang dilakukan oleh Cobb dan M.A Seale, menunjukkan hasil bahwa adanya hubungan antara kebijakan physical distancing terhadap peningkatan kasus COVID-19 sebesar 6,6\% (Cobb dan Seale, 2020). Physical distancing merupakan serangkaian tindakan menjaga jarak fisik antar individu dengan individu lainnya dalam upaya pengendalian infeksi non farmasi yang memiliki tujuan untuk menghentikan atau memperlambat penyebaran (Valerisha dan Putra, 2020).

Berdasarkan studi pendahuluan yang dilakukan pada masyarakat yang berdomisili di wilayah DKI Jakarta, dengan melakukan wawancara kepada 10 orang masyarakat. Dari hasil wawancara tersebut 8 dari 10 masyarakat menyatakan masyarakat memiliki kesadaran untuk melakukan perilaku pencegahan COVID-19 bukan karena alasan adanya imbauan pemerintah melainkan kesadaran yang timbul dari dalam diri sendiri agar terhindar dari penyakit COVID19, informasi kesehatan terkait pencegahan penularan COVID-19 yang disampaikan dikemas secara menarik sehingga masyarakat mudah memahami informasi kesehatan yang diberikan, dan kebijakan physical distancing yang diberlakukan oleh pemerintah efektif memutus mata rantai penularan COVID-19. Lalu dua orang menyatakan penyampaian promosi kesehatan melalui media sosial tidak efektif karena tidak semua masyarakat memiliki media sosial sehingga penyampaian informasi tidak dapat tersampaikan oleh masyarakat yang tidak memiliki media sosial.

Tujuan penelitian ini adalah untuk mengetahui hubungan promosi kesehatan melalui media sosial, dan kebijakan physical distancing terhadap perilaku pencegahan COVID-19 pada masyarakat perkotaan tahun 2020. 


\section{METODE}

Jenis penelitian ini adalah penelitian kuantitatif. Desain penelitian yang digunakan adalah cross-sectional, yaitu teknik pengumpulan data penelitian yang dilaksanakan sekaligus pada saat itu juga (point time approach) (Arikunto, 2020). Data variabel dependen dan variabel independen diambil dalam waktu yang bersamaan untuk mengetahui hubungan promosi kesehatan melalui media sosial dan kebijakan physical distancing terhadap pencegahan COVID19 tahun 2020. Pengumpulan data yang digunakan dalam penelitian ini adalah data primer dan data sekunder. Data primer diperoleh melalui observasi dan alat pengumpulan data yaitu kuesioner yang disebarkan melalui google form dengan sasaran masyarakat perkotaan yang berdomisili wilayah DKI Jakarta. Data sekunder yaitu data yang diperoleh melalui data situs resmi COVID-19 World Health Organization dan data pemantauan COVID-19 di wilayah DKI Jakarta.

Penelitian ini dilakukan pada bulan Agustus 2020. Populasi adalah keseluruhan subjek penelitian (Sugiyono, 2016). Populasi penelitian ini adalah seluruh masyarakat perkotaan yang berdomisili di wilayah DKI Jakarta tahun 2020 yaitu sebesar 10.570 .000 jiwa. Sampel ialah bagian dari jumlah dan karakteristik yang dimiliki oleh suatu populasi. Teknik pengambilan sampel menggunakan accidental sampling. Accidental sampling adalah metode dalam menentukan sampel beralaskan kebetulan, yaitu masyarakat yang secara kebetulan/insidental bertemu dengan peneliti dapat digunakan sebagai sampel, bila orang yang ditemui sesuai dengan sumber data (Sugiyono, 2016). Selama penelitian berlangsung pada Agustus 2020 diperoleh sampel sebanyak 100 responden.

Syarat sampel harus memenuhi beberapa kriteria-kriteria, diantaranya: kriteria inklusi merupakan karakteristik subjek umum penelitian pada populasi. Dimana kriteria yang perlu dipenuhi oleh setiap anggota populasi yang dapat diambil sebagai sampel yaitu masyarakat yang berdomisili di wilayah DKI Jakarta, bersedia menjadi responden penelitian, dan bukan masyarakat yang terkena COVID-19 dan berdomisili di wilayah DKI Jakarta; Kriteria eksklusi adalah kriteria inklusi yangdikeluarkan. Kriteria eksklusinya adalah masyarakat yang datanya tidak lengkap dalam pengisian kuesioner; serta kriteria non inklusi penelitian ini adalah kriteria yang tidak perlu dipenuhi oleh setiap populasi yang dapat diambil sebagai sampel. Kriteria non inklusi yaitu bukan masyarakat yang berdomisili di wilayah dki Jakarta, tidak bersedia menjadi responden, masyarakat yang terkena COVID-19. Analisis univariat bertujuan untuk mendeskripsikan karakteristik masing- masing variabel yang diteliti. Analisis ini hanya menghasilkan distribusi frekuensi dan persentase dari tiap variabel serta jumla responden yang diteliti. Bentuk analisis univariat tergantung dari jenis datanya. Pada penelitian ini menggunakan data numerik sehingga menampilkan distribusi frekuensi dan persentase dari tiap variabel, terdiri dari independen: promosi kesehatan melalui media sosial dan kebijakan physical distancing, serta dependen: perilaku pencegahan COVID-19.

Uji statistik menggunakan uji korelasi Pearson Correlation Product Moment. merupakan uji statistik yang menerangkan derajat hubungan linier (searah bukan timbal balik) antara dua variabel atau lebih dimana skalanya berskala interval. Uji korelasi digunakan untuk mencari hubungan variable bebas $(X)$ dengan variabel terikat $(Y)$ dan data berbentuk interval dan ratio (Sugiyono, 2016). Kelompok sampel, dalam hal ini uji yang cocok digunakan adalah uji korelasi Pearson Correlation Product Moment. Jika hubungan dua variabel tidak linier, maka koefesien korelasi Pearson tersebut tidak mencerminkan kekuatan hubungan dua variabel yang sedang diteliti, meski kedua variabel mempunyai hubungan kuat. Koefisien korelasi ini disebut koefisien korelasi Pearson karena diperkenalkan pertama kali oleh Karl Pearson tahun 1990 (Sugiyono, 2016). Koefisien korelasi adalah ukuran yang dipakai untuk mengetahui derajat hubungan antara variabel-variabel. Koefisien korelasi menurut Sugiyono yaitu koefisien korelasi 0,00-0,199 artinya memiliki tingkat hubungan yang sangat rendah, koefisien korelasi 0,20-0,399 artinya memiliki tingkat hubungan yang rendah, koefisien korelasi 0,40-0,599 artinya memiliki tingkat hubungan yang sedang, koefisien korelasi 0,60-0,799 artinya memiliki tingkat hubungan yang kuat, dan koefisien korelasi 0,80-1,00 artinya memiliki tingkat 
hubungan yang sangat kuat. Dan nilai korelasi koefisien menurut sugiyono yaitu jika nilai $r>0$, artinya telah terjadi hubungan yang linier positif, jika nilair $<0$, artinya telah terjadi hubungan yang linier negatif, jika nilai $r=0$, artinya tidak ada hubungan sama sekali, dan jika nilai $r=1$ atau $r=-1$, telah terjadi hubungan linier sempurna (Sugiyono, 2016).

Hasil analisis kemudian dibandingkan dengan teori dalam tinjauan pustaka dan hasil penelitian-penelitian sebelumnya, kemudian dibuatlah suatu kesimpulan serta saran yang membangun dan sesuai dengan kondisi di lapangan. Data dalam penelitian ini disajikan dalam beberapa bentuk yaitu penyajian data dalam bentuk teks dilakukan untuk mendeskripsikan atau memberikan penjelasan dari data yang telah disajikan dalam bentuk tabel. Penyajian data secara tabular yaitu memberikan keterangan berbentuk angka, dan grafik yaitu suatu rangka yang digunakan untuk memberikan gambaran tentang suatu data dari penyaji materi kepada para penerima materi dalam proses menyampaikan informasi.

HASIL

\section{Analisis Univariat}

Berdasarkan hasil penelitian (lihat Tabel 1), menunjukkan bahwa dari 100 responden masyarakat perkotaan yang berdomisili di wilayah DKI Jakarta, responden yang menerapkan perilaku pencegahan COVID-19 memiliki nilai minimal sebesar 22 dan nilai maksimal sebesar 45 dengan nilai rata-rata (mean) sebesar 35,00 dan nilai median sebesar 35,00, dengan skor terendah sebesar 9 dan skor tertinggi sebesar 45. Berdasarkan responden yang menilai promosi kesehatan melalui media sosial merupakan perilaku yang tepat dalam pencegahan COVID-19 memiliki nilai minimal sebesar 48 dan nilai maksimal sebesar 95 dengan nilai ratarata (mean) sebesar 77,26 dan nilai median sebesar 77,00, dengan skor terendah sebesar 19 dan skor tertinggi sebesar 95, dan berdasarkan responden yang menilai kebijakan physical distancing merupakan perilaku yang tepat dalam pencegahan COVID-19 memiliki nilai minimal sebesar 35 dan nilai maksimal sebesar 69 dengan nilai rata-rata (mean) sebesar 55,00 dan nilai median sebesar 55,00 dengan skor terendah sebesar 14 dan skor tertinggi sebesar 70 .

Tabel 1

Distribusi Frekuensi Responden Berdasarkan Variabel yang Diteliti

\begin{tabular}{lcccc}
\hline \multicolumn{1}{c}{ Variabel } & Mean & Median & Min-Max & SD \\
\hline Perilaku Pencegahan COVID-19 & 35,00 & 35,00 & $22-45$ & 4,935 \\
$\begin{array}{l}\text { Promosi Kesehatan Melalui Media } \\
\text { Sosial }\end{array}$ & 77,26 & 77,00 & $48-95$ & 11,285 \\
Kebijakan Physical Distancing & 55,00 & 55,00 & $35-69$ & 7,530 \\
\hline
\end{tabular}

Analisis Bivariat

Tabel 2 menunjukkan hasil analisis korelasi Pearson Correlation Product Moment dengan $p$-value sebesar $0,001<$ nilai $(\alpha)$ pada taraf nyata 0,01 yang berarti ada hubungan yang signifikan antara promosi kesehatan melalui media sosial dengan perilaku pencegahan COVID19. Dengan nilai korelasi ditunjukkan nilai $r=0,315$ yang menurut tingkat keeratan menunjukkan bahwa terjadi hubungan yang rendah. Sedangkan arah hubungan bernilai postif sehingga hubungan bersifat searah. Semakin efektif media dalam pemberian promosi kesehatan, maka meningkatnya perilaku individu dalam melakukan pencegahan COVID-19.

Menurut hasil analisis diketahui bahwa dari 100 responden, menunjukkan hasil analisis korelasi Person dengan $p$-value sebesar $0,000<$ nilai nilai $(\alpha)$ pada taraf nyata 0,01 yang berarti berarti ada hubungan yang signifikan antara kebijakan physical distancing dengan perilaku pencegahan COVID-19. Dengan nilai korelasi ditunjukkan nilai $r=0,973$ yang menurut tingkat keeratan menunjukkan bahwa terjadi hubungan yang sangat kuat. Sedangkan arah hubungan bernilai postif sehingga hubungan bersifat searah. Semakin ketatnya kebijakan physical 
distancing yang diberlakukan oleh pemerintah maka, meningkatnya pula perilaku individu dalam melakukan pencegahan COVID-19.

Tabel 2

Hasil Analisis Bivariat

\begin{tabular}{lcc}
\hline \multicolumn{1}{c}{ Variabel } & P-Value & Correlation Coefficient \\
\hline Promosi Kesehatan dengan Pencegahan COVID-19 & 0,001 & 0,315 \\
$\begin{array}{l}\text { Kebijakan Physical Distancing dengan Pencegahan } \\
\text { COVID-19 }\end{array}$ & 0,000 & 0,973 \\
\hline
\end{tabular}

\section{BAHASAN}

Hasil penelitian didapatkan ada hubungan promosi kesehatan melalui media sosial terhadap perilaku pencegahan COVID-19 pada masyarakat perkotaan tahun 2020. Semakin efektif media dalam pemberian promosi kesehatan, maka perilaku individu dalam melakukan pencegahan COVID-19 semakin meningkat.

Hasil penelitian Siswatibudi (2016) memiliki taraf signifikan sebesar 0,00 $<0,05$ ini berarti $\mathrm{H}$ yang menyatakan facebook messenger sebagai media promosi kesehatan reproduksi membuktikan penggunaan media berupa teknologi yang digunakan dalam dunia virtual menciptakan ilusi bahwa orang-orang yang berinteraksi berada dalam ruang dan waktu yang sama. Kekuatan ilusi ini menjadikan seseorang seakan-akan berada dekat dengan subjek atau lawan komunikasinya. Meski demikian, komunikasi dalam dunia virtual mampu dalam meningkatkan pengetahuan serta memungkinkan adanya perubahan perilaku (Siswatibudi, Paramastri, dan Lazuardi, 2016). Penilitian ini sejalan pula dengan penelitian yang dilakukan oleh Sari yang menunjukkan taraf signifikan sebesar $0,00<0,05$. ini berarti $\mathrm{H}$ yang menyatakan promosi kesehatan sadari melalui instagram memberikan kemudahan pada pengguna dalam melakukan penyebaran informasi kesehatan secara visual seluas mungkin dengan tampilan yang menarik yang melibatkan pemanfaatan media sosial Instagram untuk meningkatkan pengetahuan, sikap dan persepsi dalam perubahan perilaku (Sari dan Nabila, 2019).

Penggunaan media sosial dapat meningkatkankan akses masyarakat terhadap memperoleh informasi kesehatan, dan dapat mempromosikan kesehatan dalam upaya perubahan perilaku yang positif, dengan demikian media sosial dapat berkolaborasi dan melengkapi promosi kesehatan yang selama ini masih konvensional (Levac, 2018).

Menurut asumsi peneliti bahwa dengan adanya promosi kesehatan melalui media sosial terhadap perilaku pencegahan COVID-19 memudahkan masyarakat dalam memperoleh dan mengakes informasi kesehatan. Media sosial dapat menjadi alat yang unggul dengan jangkauan dan interaktivitas luas. Teknologi berupa media sosial memfasilitasi pengetahuan masyarakat yang lebih baik tentang penyakit dan pencegahannya. Akses informasi kesehatan saat ini yang sudah berkembang dan memungkinkan seseorang termasuk masyarakat perkotaan dapat meningkatkan literasinya. Dengan adanya berbagai sumber informasi seperti media massa/internet, media cetak/brosur, forum diskusi, dan penyuluhan dapat memudahkan seseorang termasuk masyarakat perkotaan dalam mengakses informasi mengenai penyakitnya dan memahami informasi yang telah mereka dapat untuk menentukan keputusan dalam meningkatkan kesehatannya.

Hasil penelitian menunjukkan adanya hubungan kebijakan physical distancing terhadap perilaku pencegahan COVID-19 pada masyarakat perkotaan tahun 2020. Hal ini dikarenakan semakin ketatnya kebijakan physical distancing yang diberlakukan oleh pemerintah, yang akibatnya meningkat pula perilaku individu dalam melakukan pencegahan COVID-19. Penelitian ini sejalan dengan penelitian Chu DK dengan odds ratio [aOR]0,18 $95 \% \mathrm{Cl}$ 0,09 to 0,38 ; risk different [RD]-10,2\%, $95 \% \mathrm{Cl}-11,5$ to $-7,5$; moderate certainly) menyatakan 
bahwa menjaga jarak fisik $1 \mathrm{~m}$ atau physical distancing, penggunaan masker wajah termasuk Respirator N95 atau masker serupa dan masker bedah dan perlindungan wajah efektif dalam mengurangi risiko penularan virus COVID-19 (Chu et al, 2020). Dan penelitian ini sejalan pula dengan penelitian yang dilakukan oleh MacIntyre dan Wang dengan menunjukkan hasil odds ratio [aOR]0,18 95\% $\mathrm{Cl} 0,09$ to 0,38 dan menyatakan bahwa physical distancing menurunkan resiko penularan COVID-19 sebesar 82\% dengan menjaga jarak fisik 1 meter satu dengan yang lainnya (Maclntyre dan Wang, 2020).

Physical distancing yang berkaitan dengan interaksi antar-manusia untuk menjaga eksistensi dan keberlangsungan hidup, selain itu efektif dilakukan untuk menvegah penularan infeksi virus yang dapat ditularkan melalui kontak fisik yang meliputi kontak seksual, kontak fisik tidak langsung misalnya dengan menyentuh permukaan yang terkontaminasi, atau transmisi melalui udara,atau dapat juga mengenai percikan atau droplet yang berasal dari batuk atau bersin (Yusup et. al, 2020).

Berdasarkan teori yang dikembangkan oleh Lawrence Green, kesehatan seseorang atau masyarakat dipengaruhi oleh dua faktor pokok yaitu faktor perilaku (behavior causes) dan faktor diluar perilaku (non-behavior causes). Sementara faktor perilaku (behavior causes) dipengaruhi oleh tiga faktor yakni : faktor predisposisi (Predisposing Factors) yang meliputi umur, pekerjaan, pendidikan, pengetahuan dan sikap, faktor pemungkin (Enabling Factors) yang terwujud dalam lingkungan fisik dan jarak ke fasilitas kesehatan, dan faktor penguat (Reinforcing Factors) yang terwujud dalam kebijakan pemerintah, dukungan keluarga, dan tokoh masyarakat (Notoatmodjo, 2020).

Menurut asumsi peneliti bahwa dengan kebijakan physical distancing yang dilakukkan oleh pemerintah untuk mengurangi dampak penyebaran infeksi virus COVID-19 di Indonesia merupakan kebijakan yang tepat dimana kebijakan yang dipilih sesuai dengan himbauan World Health Organization (WHO) terkait physical distancing yaitu pembatasan kontak fisik yang bertujuan untuk menghentikan atau memperlambat penyebaran penyakit menular. sehingga dapat meminimalkan terjadinya penularan penyakit, virus, morbiditas, dan akibat buruk lainnya yang dapat berakibat kepada kematian.

\section{SIMPULAN}

Berdasarkan hasil penelitian dapat disimpulkan variabel yang memiliki hubungan dengan tingkat keeratan yang sangat kuat terhadap perilaku pencegahan COVID-19 yaitu kebijakan physical distancing. Sedangkan promosi kesehatan melalui media sosial memiliki hubungan dengan tingkat keeratan yang rendah terhadap perilaku pencegahan COVID-19.

Pandemi COVID-19 merupakan wabah penyakit yang melanda secara global dan membuat berbagai pihak berupaya dalam mengatasinya. Berbagai imbauan dan kebijakan telah diberlakukan dalam memutus rantai penularan kasus tersebut, mulai dari imbauan cuci tangan, menerapkan etika batuk, dan menjaga jarak fisik (physical distancing). Kenyataannya dari kebijakan yang dibuat masih banyak masyarakat yang tidak patuh yang menyebabkan kasus COVID-19 mengalami kenaikan. Diharapkan masyarakat lebih memiliki kesadaran peduli dan ikut mempraktikkan himbauan-himbauan pemerintah terkait upaya pencegahan COVID19, pemerintah diharapkan mengeluarkan sanksi bagi masyarakat yang tidak patuh terhadap protokol kesehatan pencegahan COVID-19, dan tidak ragu dalam menjalankan kebijakan dalam menekan penyebaran COVID-19 serta mengedepankan koordinasi dengan berbagai pihak.

\section{PUSTAKA ACUAN}

Arikunto S. (2016). Prosedur Penelitian Suatu Pendekatan Praktik. Jakarta: Rineka Cipta.

Budhiarto. (2020). Pengantar Ilmu Perilaku Kesehatan dan Pendidikan Kesehatan Gigi. Jakarta: EGC.

Chu DK, Akl EA, Duda S, Solo K, Yaacoub S, Schünemann HJ, et al. Physical Distancing, Face Masks, and Eye Protection to Prevent Person-to-Person Transmission of SARS-CoV-2 and COVID-19: a Systematic Review and Meta-Analysis.Lancet. 2020;395(10242):1973-87. 
Cobb J., M.A Seale. Examining the Effect of Social Distancing on the Compound Growth Rate of SARSCoV-2 at the County Level (United States)Using Statistical Analyses and a Random Forest Machine Learning Model.. 2020;

Dalinama T. Urgensi Pembentukan Aturan Terkait Pencegahan Covid-19 di Indonesia. 2020;1(12):59-70.

Dana RB. Analisis Perilaku Masyarakat Indonesia dalam Menghadapi Pandemi Virus Corona (Covid-19) dan Kiat Menjaga Kesejahteraan Jiwa. SALAM J Sos dan Budaya Syar-i. 2020;7(3).

Dinkes DKI Jakarta. Data Pantauan Covid 19 DKI Jakarta [Internet]. 2020. Available from: https://corona.jakarta.go.id/id

Levac, Sullivan. Interactive Social Media Interventions for Health Behavior Change, Health Outcomes, and Health Equity in the Adult Population Cochrane Database of Systematic. 2018;(2).

Maclntyre CR, Wang Q. Physical Distancing, Face Masks, and Eye Protection for Prevention of COVID-19. Lancet [Internet]. 2020;395(10242):1950-1. Available from: http://dx.doi.org/10.1016/S0140-6736(20)31183-1

Mia SA, Mursid RN. Pola Sebaran Kejadian Penyakit Pneumonia pada Balita di Kecamatan Bergas, Kabupaten Semarang. J Kesehat Masy. 2017;5(5):744-52.

Mitasari. (2020). Mortalitas Terhadap Perkembangan Kasus COVID - 19.

Notoatmodjo, S. (2014). Ilmu Perilaku Kesehatan. Jakarta: PT. Rineka Cipta.

Perhimpunan Dokter Paru Indonesia. (2020). Panduan Praktik Klinis: Pneumonia 2019-nCoV. Jakarta: PDPI.

Putri A, Rezal F, Akifah A. Efektifitas Media Audio Visual Dan Leaflet Terhadap Peningkatan Pengetahuan, Sikap Dan Tindakan Tentang Pencegahan Penyakit Gastritis Pada Santriwati Di Pondok Pesantren Hidayatullah Putri Dan Ummusshabri Kota Kendari Tahun 2017. J Ilm Mhs Kesehat Masy Unsyiah. 2017;2(6):184073.

Rothan HA, Byrareddy SN. (2020). The Epidemiology and Pathogenesis of Coronavirus Disease (COVID-19) Outbreak.

Sari ZA Nabila N. Promosi Kesehatan "Sadari" Menggunakan Instagram pada Mahasiswi Non Kesehatan Universitas Andalas. Media Kesehat Masy Indones. 2019;15(3):253.

Siswatibudi H, Paramastri I, Lazuardi L. Facebook Messenger sebagai Media Promosi Kesehatan Reproduksi Remaja Studi di SMP Muhammadiyah Depok Sleman Yogyakarta. Permata Indones [Internet]. 2016;710-25. Available from: http://www.permataindonesia.ac.id/wp-content/uploads/2016/08/02.-JurnalPI_Harpeni.pdf

Sugiyono. (2016). Metode Penelitian Pendidikan Pendekatan Kuantitatif, Kualitatif, dan R\&D. Bandung: Alfabeta.

Valerisha A, Putra MA. Pandemi Global COVID-19 dan Problematika Negara-Bangsa: Transparansi Data Sebagai Vaksin Socio-digital ? Pandemei Virus Covid-19 [Internet]. 2020;(Edisi Khusus):131-7. Available from: https://doi.org/10.26593/jihi.v0i0.3871.131137

World Health Organization. WHO 2020. Coronavirus disease 2019 (COVID-19) Situation Report-70 [Internet]. 2020. Available from: https://www.who.int/[Accessed March 30; cited 2020 August 312020 ].

Wulantari A, Rahmayanti Y. Gambaran Pengguna Media Sosial Facebook dan Instagram dalam Promosi Kesehatan Bahaya Merokok. 2019;1(2):47-55. Available from: http://jurnal.abulyatama.ac.id/index.php/kandida

Yusup DK, Badriyah M, Suyandi D, Asih VS. Pengaruh Bencana Covid-19, Pembatasan Sosial, dan Sistem Pemasaran Online Terhadap Perubahan Perilaku Konsumen dalam Membeli Produk Retail. 2020;1(1):1-10. Available from: http://digilib.uinsgd.ac.id/30872/1/Deni \& Team - Artikel Karya IImiah 2020.pdf 